\title{
Differential Regulation of the p21/WAF-1 and $m d m 2$ Genes after High-Dose UV Irradiation: p53-Dependent and p53-Independent Regulation of the $m d m 2$ Gene
}

\author{
Lin Wu and Arnold J. Levine \\ Department of Molecular Biology, Princeton University, Princeton, \\ New Jersey, U.S.A.
}

\begin{abstract}
Background: DNA damage in mammalian cells stabilizes the $\mathrm{p} 53$ protein which then functions as a cell cycle checkpoint by leading to growth arrest or apoptosis. p53 is a transcription factor and positively regulates the expression of the p21/WAF-1 gene and the $m d m 2$ gene. After high-dose UV irradiation, p53 increases the expression of the p21/WAF-1 gene immediately ( 2 to 5 hours after irradiation) while the induction of the $m d m 2$ gene is delayed (8 to 12 hours after irradiation). Experiments presented here explore this differential expression of two different p53-regulated genes.

Materials and Methods: IP-Western (protein) and Northern (mRNA) blot experiments are used to follow $m d m 2$ and p21/WAF-1 expression in primary rat or mouse cells after a low-dose $\left(4 \mathrm{~J} / \mathrm{m}^{2}\right)$ or a high-dose $(20$ $\mathrm{J} / \mathrm{M}^{2}$ ) of UV irradiation. Northern blot and nuclear
\end{abstract}

\begin{abstract}
run-on experiments are employed to study mRNA stability as well as transcription rates of selected genes. Results: After high-dose UV irradiation, p53 is rapidly stabilized and the expression of p21/WAF1 is immediately increased. By contrast, both protein and mRNA levels of $m d m 2$ first decrease in a p53-independent manner, and later increase in a p53-dependent manner. The initial decline of $m d m 2$ expression following high-dose UV irradiation is UV-dosage dependent and regulated at the level of transcription.

Conclusion: p53 regulates two genes, p21/WAF1 (blocks cell cycle progression) and $m d m 2$ (reverses p53 activity), that mediate opposite actions. This process is regulated in a temporal fashion after high-dose UV irradiation, so that cell cycle progression can be halted while DNA repair continues prior to reversal of p53-mediated arrest by $m d m 2$.
\end{abstract}

\section{INTRODUCTION}

The $m d m 2$ gene was originally identified as a gene that was amplified and overexpressed in a spontaneously transformed mouse 3T3 cell line (1). Two lines of evidence suggest that $m d m 2$ has oncogenic potential. First, $m d m 2$ is amplified in a significant percentage of human sarcomas (2-4). It is also overexpressed in a variety of other types of tumors, including leukemias (5), breast carcinomas (6), lymphomas (7), and malignant glio-

Address correspondence and reprint requests to: Dr. Arnold J. Levine, Department of Molecular Biology, Princeton University, Lewis Thomas Laboratory, Princeton, NJ 085441014, U.S.A. Tel.: 609-258-5990; Fax: 609-258-1704; e-mail: alevine@molbiol.princeton.edu mas (8). Second, overexpression of $m d m 2$ immortalizes primary cultures of rodent fibroblasts and cooperates with an activated ras gene to transform these cells $(9,10)$. The oncogenic properties of Mdm2 have been attributed to its ability to complex with p53 and inhibit p53's tumor suppression functions $(2,10-13)$. p53 is a transcription factor which regulates the expression of a number of genes involved in cell cycle control and the apoptotic pathways. For instance, p53 activates expression of the cyclin-dependent kinase inhibitor p21/WAF1 (14), the growth inhibitory protein GADD45 (15) and the apoptosispromoting protein Bax (16). In addition, it was recently shown that $\mathrm{p} 53$ represses the expression 
of the microtubule-associated protein MAP4 (17). It is believed that these types of transcriptional regulation by $\mathrm{p} 53$ are directly responsible for its tumor suppression function. Mdm2 negatively regulates $\mathrm{p} 53$ function by binding to $\mathrm{p} 53$ and blocking its transcriptional activities. Interestingly, the $m d m 2$ gene itself can be induced by p53 $(18,19)$. This creates a feedback loop in which p53 induces $m d m 2$ expression, and Mdm2 binds to p53 and inhibits its transactivation activity. This loop results in the autoregulation of $m d m 2$ expression as well as modulating p53's transcriptional activity which is essential for controlling cell cycle progression $(18,20)$. In fact, lack of p53 regulation by $\mathrm{Mdm} 2$ can be lethal; mice deficient in $\mathrm{Mdm} 2$ die in early stages of embryonic development and this embryonic lethality can be rescued or suppressed by the absence of p53 $(21,22)$.

Following exposure to DNA-damaging agents such as UV or $\gamma$ irradiation, the cellular levels of $\mathrm{p} 53$ rise due to posttranslational stabilization of the protein $(15,23,24)$. The elevated p53 levels induce expression of downstream genes such as p2l/WAF1 that at least in part results in cell cycle arrest, presumably to allow DNA repair to occur in the absence of replication $(14,15,24)$. In certain cell types, the elevated p53 protein induces apoptosis after DNA damage, possibly by increasing expression of bax (16). Expression of $m d m 2$ is also induced in response to DNA damage in a p53-dependent manner $(25,26)$. The role for $m d m 2$ in response to UV or $\gamma$ irradiation is thought to function in a "feedback loop" mechanism inhibiting the transcriptional activity of p53 when it is no longer needed after repair is complete. In fact, the timing of $m d m 2$ induction is critical; it was previously demonstrated in a tumor cell line that the induction of $m d m 2$ expression was delayed when compared to the rapid increase of $\mathrm{p} 53$ protein levels, and $m d m 2$ expression was best correlated with recovery of normal rates of DNA synthesis, presumably after DNA repair $(25,26)$.

To understand the mechanism by which the $m d m 2$ expression is regulated following irradiation, the expression profiles of the $m d m 2$ gene were examined using primary rat embryo fibroblasts (REF) and mouse embryo fibroblasts (MEF). After a high dose of UV irradiation (20 $\mathrm{J} / \mathrm{M}^{2}$ ) the induction of $m d m 2$ mRNA and protein was delayed. Surprisingly, the expression of $m d m 2$ protein and mRNA actully declined immediately after UV treatment. This initial decrease in $m d m 2$ expression was dependent upon the UV dosage. Unlike high doses of UV irradiation, lower doses of UV irradiation $\left(4 \mathrm{~J} / \mathrm{M}^{2}\right)$ induce the $m d m 2$ gene shortly after treatment with no initial decrease in $m d m 2$ protein and mRNA levels. A high-dose UV treatment of the MEF derived from a p53 knockout mouse (with no p53) failed to cause an increase of $m d m 2$ mRNA or protein levels; yet it resulted in the initial decrease of $m d m 2$ expression. Therefore, the expression of $m d m 2$ is initially down-regulated in a p53-independent fashion and then induced in a p53dependent fashion in response to a high dose of UV irradiation $\left(20 \mathrm{~J} / \mathrm{M}^{2}\right)$. Furthermore, it is shown that UV irradiation has little effect on the stability of the $m d m 2$ mRNA and the initial down-regulation of $m d m 2$ was controlled at the level of transcriptional initiation. These results suggest that after high-dose UV irradiation, Mdm2 levels first decrease, allowing for the maximal transcriptional activity of $\mathrm{p} 53$ which is essential for $\mathrm{p} 53$ to function as a cell cycle checkpoint; $m d m 2$ is later induced by p53, inhibiting p53 transcriptional activity after a sufficient period of time for DNA repair. These data indicate that $m d m 2$ gene expression is regulated in both p53-independent and p53-dependent manner, and that both could contribute to the regulation of cell cycle progression in response to high-dose UV irradiation.

\section{MATERIALS AND METHODS}

\section{Cell Culture and UV Treatment}

All cells except $\mathrm{SP} 2 / 0$ were grown at $37^{\circ} \mathrm{C}$ in Dulbecco's modified Eagle's medium (DMEM) supplemented with $10 \%$ heat-inactivated fetal bovine serum (FBS) in a humidified $5 \% \mathrm{CO}_{2}$ atmosphere. SP2/0 cells were grown in suspension in Rosewell Park Memorial Institute 1640 media (RPMI) with 10\% FBS under the same conditions.

Cells were exposed to UV light essentially as described (25). The medium was removed and the cells were irradiated with an $8-\mathrm{W}$ germicidal lamp delivering $2 \mathrm{~J} / \mathrm{M}^{2} / \mathrm{sec}$ at a distance of 38.5 $\mathrm{cm}$. The dose was calibrated with a J-225 shortwave UV meter (Ultraviolet Products, San Gabriel, CA).

\section{IP-Western Analysis}

The IP-Western experiments were performed as described (25). Briefly, 2 to $3 \mathrm{mg}$ of each lysate 
were incubated with monoclonal antibody pAb2A10 (specific for mdm2) or monoclonal antibody pAb421 (specific for p53), the immunoprecipitates were separated on a SDS-polyacrylamide gel, and blotted onto Immobilon-P membrane (Millipore, Bedford, MA). The membranes were incubated with anti-mdm2 serum or pAb421. Antibody binding was detected with ${ }^{125}$ I-protein A (NEN), and quantitation was done with a Molecular Dynamics Phospho-Imager.

\section{Northern Analysis}

Total cellular RNA was isolated with TRIzol reagent (BRL). $20 \mu \mathrm{g}$ of total RNA was used for Northern analysis on $1.2 \%$ agarose gel containing $6.7 \%$ formaldehyde. The RNA was transferred to GeneScreen (Dupont, Boston, MA) by capillary transfer in $20 \times$ SSC, and then crosslinked by exposure to UV followed by baking at $80^{\circ} \mathrm{C}$ for 2 to 4 hours. Blots were prehybridized for several hours at $65^{\circ} \mathrm{C}$ in Church buffer containing $0.5 \mathrm{M} \mathrm{NaHPO}_{4} \mathrm{pH} 7.0,1 \%$ BSA, $7 \%$ SDS and $1 \mathrm{mM}$ EDTA. Hybridizations were for 16 to 24 hours at $65^{\circ} \mathrm{C}$ in fresh Church buffer with $10^{8}$ $\mathrm{cpm}$ of a randomly primed ${ }^{32} \mathrm{P}$-labeled DNA probe. The filters were washed twice in a solution of $1 \times \mathrm{SSC}$ and $0.1 \%$ SDS for $20 \mathrm{~min}$ at $65^{\circ} \mathrm{C}$, and further washed twice in a solution of $0.2 \times$ SSC and $0.1 \%$ SDS for $20 \mathrm{~min}$ at $65^{\circ} \mathrm{C}$. The washed filters were exposed to a Molecular Dynamics Phospho-Imager for quantification and to Kodak films for photography. Equal loading of RNA was confirmed by staining with ethidium bromide and hybridizing with cDNA probes of the GAPDH (glyceraldehyde-3-phosphate dehydrogenase) or $\beta$-actin genes.

\section{Nuclear Run-on Analysis}

Nuclear run-on analysis was performed basically as described (27). Briefly, the nuclei were isolated from the SP2/0 cells using NP-40 lysis buffer ( $10 \mathrm{mM}$ Tris $\cdot \mathrm{HCl}$ pH 7.4, $10 \mathrm{mM} \mathrm{NaCl}, 3$ $\mathrm{mM} \mathrm{MgCl}{ }_{2}$ and $0.5 \% \mathrm{NP}-40$ ). These SP $2 / 0$ cells were either untreated, or were harvested at 6 hours after a treatment of $20 \mathrm{~J} / \mathrm{M}^{2} \mathrm{UV}$ irradiation. Run-on transcription assays were done with $2 \times 10^{7}$ nuclei of each sample for $15 \mathrm{~min}$ utes at $30^{\circ} \mathrm{C}$ in the reaction buffer containing 5 $\mathrm{mM}$ Tris $\cdot \mathrm{HCl}, 2.5 \mathrm{mM} \mathrm{MgCl}_{2}, 0.15 \mathrm{M} \mathrm{KCl}, 0.5$ mM of each of ATP, CTP, and GTP, and $15 \mu \mathrm{Ci}$ of $\left[\alpha{ }^{32} \mathrm{P}\right]$ UTP (NEN). The newly transcribed ${ }^{32} \mathrm{P}-$ labeled RNA molecules were extracted, denatured, and precipitated. The labeled RNA pellets were resuspended in TES solution (10 mM TES, $10 \mathrm{mM}$ EDTA and $0.2 \%$ SDS) and a small aliquot of each sample was counted. Equal amounts (greater than $5 \times 10^{6} \mathrm{cpm}$ ) of the labeled RNA of each sample were hybridized with a nylon filter bound by the various Bluescript plasmids containing cDNAs of mdm2, p21/WAF1, GAPDH and $\beta$-actin. The filters were washed twice in the solution of $2 \times \mathrm{SSC}$ at $65^{\circ} \mathrm{C}$ for 1 hour, and once in the solution of $1 \times \mathrm{SSC}$ and $10 \mu \mathrm{g} / \mathrm{ml}$ RNase at $37^{\circ} \mathrm{C}$. The washed filters were exposed to a Molecular Dynamics Phospho-Imager for quantification and to Kodak films for photography.

\section{RESULTS}

\section{Mdm2 Protein Levels Change in Response to UV Irradiation}

It was previously reported that $\mathrm{Mdm} 2$ protein levels increased in a p53-dependent manner following UV irradiation in C127 tumor cells. However, the $m d m 2$ induction was delayed when the cells were treated with a high dose of UV irradiation $\left(20 \mathrm{~J} / \mathrm{M}^{2}\right)$ and this delayed induction of Mdm2 was correlated with the recovery of cells to produce a normal rate of DNA synthesis or entry into S-phase (25). These observations indicated that there might be multiple mechanisms regulating the $m d m 2$ gene expression in response to UV irradiation. In this study, primary rat embryo fibroblasts (REF) were used for examining Mdm2 levels in response to UV irradiation. Following UV treatment at a dose of $20 \mathrm{~J} / \mathrm{M}^{2}$, the primary REF cells were harvested at 2.5, 5, 8, 12, and 24 hours posttreatment. The cellular levels of the $m d m 2$ protein were then detected by an immunoprecipitation-Western blot analysis, in which the soluble $m d m 2$ proteins were immunoprecipitated, separated on a SDS-polyacrylamide gel, and transferred onto a blot for Western analysis. After UV irradiation, the levels of the $m d m 2$ protein first decreased and then increased starting at 8 to 12 hours post irradiation (Fig. 1A). The levels of $\mathrm{Mdm} 2$ and $\mathrm{p} 53$ at each time point after UV irradiation were compared to the untreated level (zero time level) respectively, and the relative protein levels versus time after UV irradiation were plotted (Fig. 1B). Consistently with the previous report in $\mathrm{C} 127$ cells (25), the p53 protein began accumulating immediately (2.5 hours after treatment), increased to more than 30 -fold higher than the original level by 8 hours and stayed at that level even at 24 hours 
A. Hours after UV $\left(20 \mathrm{~J} / \mathrm{M}^{2}\right)$ $\begin{array}{llllll}0 & 2.5 & 5 & 8 & 12 & 24\end{array}$ Mdm2:

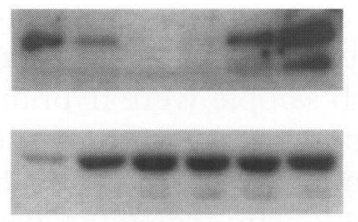

p53:

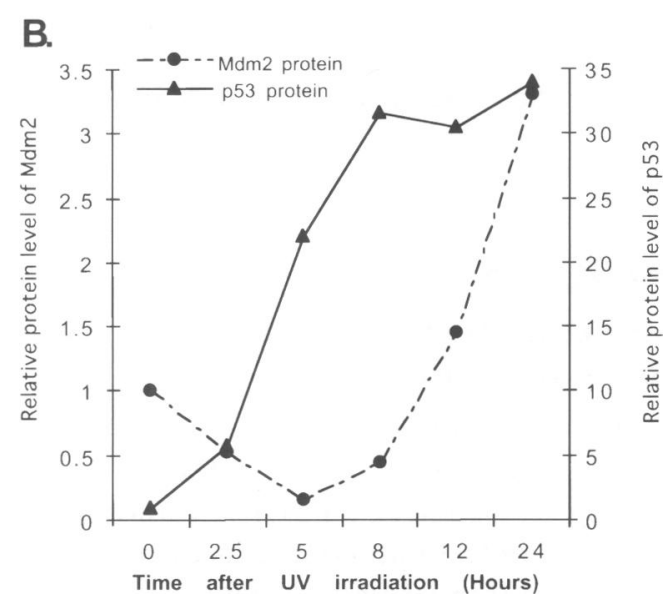

FIG. 1. Mdm2 protein levels change in response to a high dose of UV irradiation

(A) IP-Western analysis of Mdm2 and p53. Primary Rat Embryo Fibroblasts (REF) were irradiated with a UV dose of $20 \mathrm{~J} / \mathrm{M}^{2}$ and harvested at the indicated times following treatment. Two to three mg of cell lysate was incubated with monoclonal antibody pAb2A10 (specific for Mdm2) or monoclonal antibody pAb421 (specific for p53). The immunoprecipitates were electrophoresed in a SDS-polyacrylamide gel and blotted onto a membrane. Western analysis was then performed with anti-Mdm2 serum for Mdm2 or pAb421 for p53 and ${ }^{125}$ I-protein A. (B) Quantitation of Mdm2 and p53 protein levels. The antibodybound ${ }^{125}$ I-protein A was quantified with a Phospho-Imager. The relative protein level was calculated by dividing the amount of protein at each time following UV treatment by the original level with no treatment. The relative protein levels of $\mathrm{Mdm} 2$ and p53 were plotted in different scales as indicated.

after UV treatment. In contrast, the level of the $m d m 2$ protein first decreased at 2.5 to 5 hours following UV treatment to a level less than $10 \%$ of the untreated level. At 8 hours after UV treatment, Mdm2 protein began to increase. By 12 hours, the level of Mdm2 was 1.5-fold higher than the original level and continued to increase until 24 hours after UV treatment. Therefore, the induction of the $m d m 2$ protein was delayed as compared to the rapidly increasing level of $\mathrm{p} 53$.
A.

$\begin{array}{lllllll}\text { Hours after UV }\left(4 \mathrm{~J} / \mathrm{M}^{2}\right) & 0 & 2.5 & 5 & 8 & 12 & 24\end{array}$

Mdm2:

p53:

B.

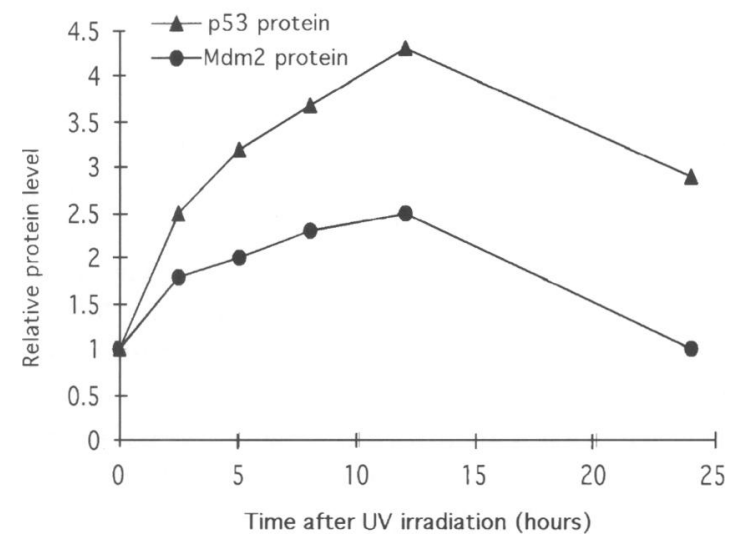

FIG. 2. Mdm2 protein levels increase in response to a low dose of UV irradiation

REF were irradiated with a UV dose of $4 \mathrm{~J} / \mathrm{M}^{2}$, analyzed and quantified as in Figure 1. (A) IP-Western analysis of Mdm2 and p53. (B) Quantitation of Mdm2 and p53 protein levels.

The initial decrease of the $m d m 2$ protein levels was not seen when the REF cells were irradiated with a low dose of UV light (Fig. 2). After REF cells were irradiated with a dose of $4 \mathrm{~J} / \mathrm{M}^{2}$ $\mathrm{UV}$, the cellular levels of Mdm2 started to increase at 2.5 hours after treatment and stayed about 2 -fold higher until 12 hours after UV treatment; meanwhile, the level of p53 was also increased but only up to 4-fold. Primary MEF cells were irradiated with high-dose or low-dose UV light, and changes in the levels of Mdm2 were similar to those observed in REF cells (data not shown).

\section{The Initial Decrease of the $m d m 2$ Protein After High-Dose UV Irradiation is Regulated at the mRNA Level}

It has been demonstrated that the induction of the $m d m 2$ protein in response to both high- and low-dose UV irradiation depends upon the transcriptional activation activity of p53 (25). To evaluate whether the initial decrease of Mdm2 


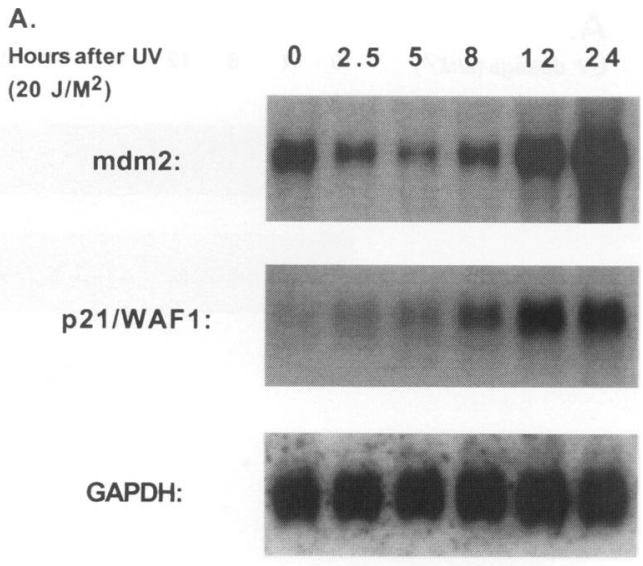

B.

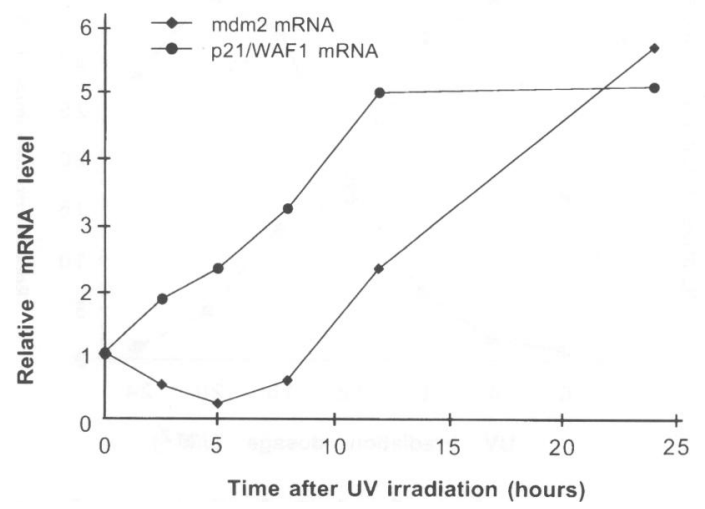

FIG. 3. Expression of Mdm2 is initially decreased and later increased in response to a high dose of UV irradiation

(A) Northern analysis. Primary MEF were treated with a UV dose of $20 \mathrm{~J} / \mathrm{M}^{2}$, and then harvested at each indicated time following treatment. Total cellular RNA was isolated and $20 \mu \mathrm{g}$ of each was used in Northern analysis. The mRNA levels of mdm2, p21/ WAF1 and GAPDH were examined with each cDNA probe as indicated. (B) Quantitation of the mRNA levels of mdm2 and p21/WAF1. The amount of ${ }^{32} \mathrm{P}$-labeled probe bound to the Northern blots was quantified on a Phospho-Imager. The relative mRNA level was calculated by dividing the amount of mRNA at each time following UV treatment by the original level with no treatment. The relative mRNA levels of mdm2 and p21/WAF1 at each time after UV were plotted as indicated. The GAPDH signal was used as a loading control.

protein was in fact due to the alterations of the $m d m 2$ gene expression following high-dose UV irradiation, Northern analysis was performed to examine the mRNA level of $m d m 2$ (Fig. 3). Total cellular RNA was extracted from the MEF cells that had been irradiated with a high dose $(20$ $\mathrm{J} / \mathrm{M}^{2}$ ) of UV light and harvested at various times after that treatment. Northern analysis using these total RNA pools showed that the $m d m 2$ mRNA level was reduced by about $80 \%$ within 5 hours. It then recovered at 8 hours, and kept increasing to 5 to 6 fold over the original level by 24 hours after treatment. This result indicated that the initial decrease of $m d m 2$ following highdose UV irradiation was regulated at the mRNA level. The same blot was probed for the mRNA level of p21/WAF1. This showed that the p21/ WAF1 mRNA level increased immediately after UV treatment. The immediate increase in the p21/WAFl mRNA level suggested that p53 is transcriptionally active after UV irradiation although the level of $m d m 2$ mRNA was downregulated. This result implied that the decrease in $m d m 2$ expression could be $\mathrm{p} 53$-independent. By 12 hours after UV irradiation, the induction of $m d m 2$ expression started while at this time the mRNA level of p21/WAFl stopped increasing and reached its maximum level. This result is consistent with the possibility that the newly produced $m d m 2$ protein could prevent further transactivation of $\mathrm{p} 21 /$ WAFl by binding to $\mathrm{p} 53$ and blocking its transactivation activity for that gene but not the $m d m 2$ gene. The mRNA level of GAPDH did not decrease after UV treatment indicating that the initial decrease of $m d m 2$ expression is not due to a general inhibition of RNA polymerase II by UV irradiation.

\section{The Decrease of $m d m 2$ Expression by UV Irradiation Is p53-Independent}

To test whether the initial decrease in $m d m 2$ mRNA in response to high-dose UV treatment could be mediated by $\mathrm{p} 53$, the expression of $m d m 2$ in cells that lack endogenous p53 was examined (Fig. 4). MEF cells from the p53 knockout mice (MEFKO p53-/-) and the cells from two p53-/- human cell lines, H1299 and Saos-2, were treated with $20 \mathrm{~J} / \mathrm{M}^{2} \mathrm{UV}$ and then harvested at various times after treatment. In all three types of cells, Mdm2 protein levels initially decreased following UV irradiation (Fig. 4A). In the case of UV-irradiated MEFKO p53-/- cells ( 40 to $50 \%$ cells were attached to plates by 24 hours after $20 \mathrm{~J} / \mathrm{M}^{2} \mathrm{UV}$ irradiation), Mdm2 protein levels were initially reduced within 12 hours and then recovered to the original level by 24 hours after treatment, presumably after DNA repair of the remaining living cells. On the other hand, the majority of H1299 and Saos-2 cells died by 24 hours following $20 \mathrm{~J} / \mathrm{M}^{2} \mathrm{UV}$ irradiation. In these two cell types, Mdm2 protein lev- 
A.

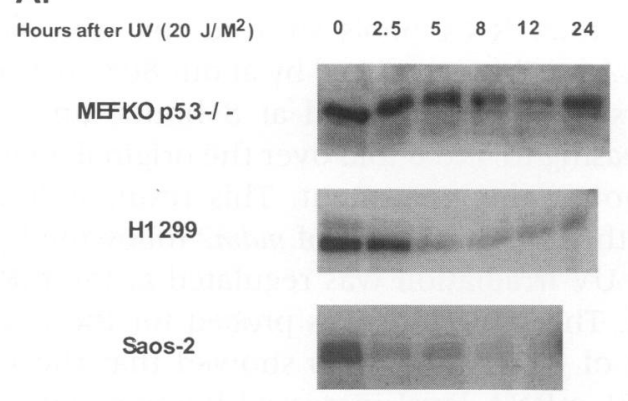

B.

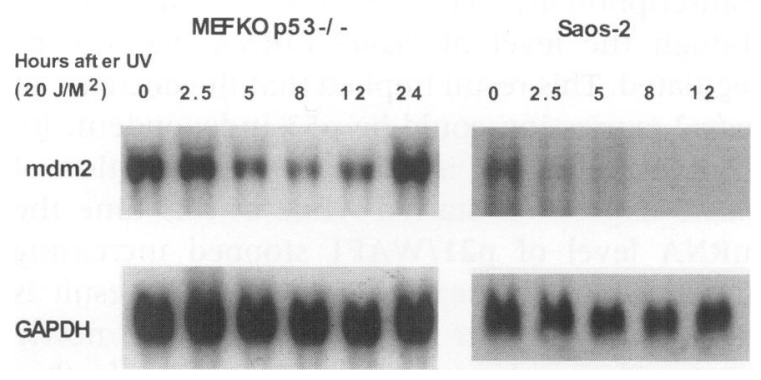

FIG. 4. The initial decrease of Mdm2 expression after high-dose UV irradiation is p53-independent

The MEF from $\mathrm{p} 53$ knockout mice (MEFKO p53-/-), H1299 cells and Saos-2 cells, all of which lack the endogenous expression of $\mathrm{p} 53$, were treated with a dose of $20 \mathrm{~J} / \mathrm{M}^{2} \mathrm{UV}$ and harvested at the indicated times. The protein levels of Mdm2 were analyzed by IP-Western (A) and the mRNA levels of $\mathrm{mdm} 2$ were examined by Northern analysis (B) as described in Figures 1 and 3.

els, which fell early, never recovered to the original level. Northern analysis (Fig. 4B) revealed that the $m d m 2$ mRNA levels also declined in MEFKO p53-1- cells and Saos-2 cells shortly after high-dose UV irradiation. These results confirmed that the increase of the $m d m 2$ expression at late time after exposure to high-dose UV irradiation relied on the presence of p53. Furthermore, these results indicate that the early decline in $m d m 2$ gene expression following high-dose UV treatment is p53-independent.

\section{Initial Decline of $m d m 2$ Expression Is UV Dosage-Dependent}

Because the initial repression of $m d m 2$ mRNA in response to irradiation was only tested when the cells were treated with a single high dose $(20$ $\left.\mathrm{J} / \mathrm{M}^{2}\right)$ or low dose $\left(4 \mathrm{~J} / \mathrm{M}^{2}\right)$ of UV irradiation, a
A.

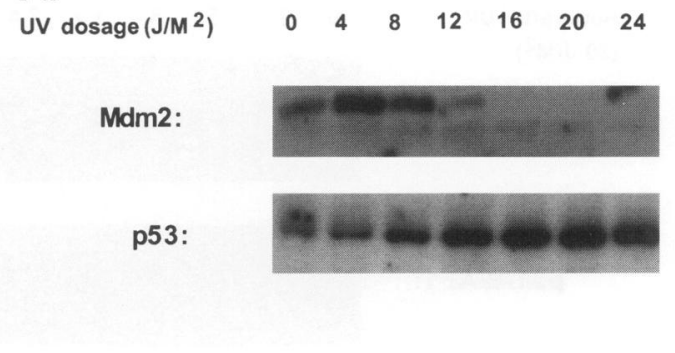

B.

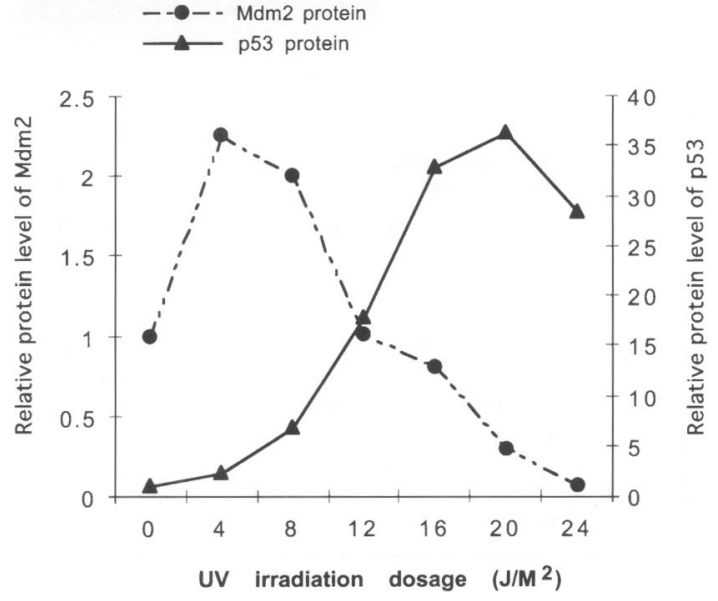

FIG. 5. Expression of $m d m 2$ changes as a function of UV dose

Primary REF cells were irradiated with UV light of the indicated doses, harvested at 6 hours after treatment and analyzed as in Figure 1. (A) IP-Western analysis of Mdm2 and p53. (B) Quantitation of Mdm2 and p53 protein levels.

dose-response curve between 0 and $24 \mathrm{~J} / \mathrm{M}^{2}$ was carried out. REF cells were irradiated with a series of UV doses and harvested after 6 hours. The levels of $\mathrm{Mdm} 2$ and $\mathrm{p} 53$ proteins were examined by an immunoprecipitation-Western blot analysis. At 6 hours after UV irradiation, the level of p53 increased in a UV-dosage dependent manner, to more than 30 -fold when the cells were treated with high-dose UV irradiation $(>16 \mathrm{~J} /$ $\mathrm{M}^{2}$ ) (Fig. 5). Mdm2 protein levels responded in quite a different manner. When the UV dose was below $8 \mathrm{~J} / \mathrm{M}^{2}$, the expression of $m d m 2$ protein was induced; when the UV dose was increased to $12 \mathrm{~J} / \mathrm{M}^{2}$, the expression of $m d m 2$ protein began to decline at 6 hours after treatment. Mdm2 protein levels dropped by $95 \%$ of its original level when the UV dose was $20 \mathrm{~J} / \mathrm{M}^{2}$ or higher. The induction of $m d m 2$ following low-dose UV 
irradiation was mediated by $\mathrm{p} 53$ because the cells lacking the endogenous wild-type p53 did not show the elevated Mdm2 level (data not shown). Following high-dose UV treatment, the $m d m 2$ expression decreased even in the presence of much higher levels of $\mathrm{p} 53$. These results suggest that the $m d m 2$ expression following high-dose UV irradiation may be initially controlled by a factor(s) which selectively prevents expression of the $m d m 2$ gene by $\mathrm{p} 53$ or other basal transcription factors. The net result is a repression of $m d m 2$ gene expression.

\section{Mdm2 Down-Regulation following Irradiation with High Doses of UV Occurs at the Level of Transcription}

The lower levels of $m d m 2$ mRNA and protein could be due to increased $m d m d 2$ mRNA instability or a decreased rate of $m d m 2$ gene transcription. In an effort to explore the mechanism by which the $m d m 2$ expression was down-regulated by high-dose UV treatment, murine SP $2 / 0$ cells were employed. These cells have very high levels of $m d m 2$ gene expression due to a translocation event that brings the mdm 2 promoter in contact with the immunoglobulin enhancer region. The $\mathrm{mdm} 2$ promoter element remains intact in these cells. IP-western analysis (Fig. 6A) and Northern blot analysis (Fig. 6B) indicated that these cells, like all of the cell lines tested in this study, showed an 80 to $90 \%$ decline of $m d m 2$ mRNA and protein at 8 hours following treatment with $20 \mathrm{~J} / \mathrm{M}^{2}$ of UV.

In order to test the effect of UV on the stability of the $m d m 2$ mRNA, the SP2/0 cells were first treated with actinomycin $D$ to inhibit transcription by RNA polymerase II. Fifteen minutes later, the cells were irradiated with $20 \mathrm{~J} / \mathrm{M}^{2}$ of UV light or were left untreated, and then these cells were harvested at various times after UV exposure. Total cellular RNA was isolated from these cells for Northern analysis (Fig. 6C), and the amount of $m d m 2$ mRNA after UV irradiation was quantified as shown in Figure 6D. The halflife of $m d m 2$ mRNA in SP2/0 cells without UV radiation is about 1.5 hours. After UV irradiation of $20 \mathrm{~J} / \mathrm{M}^{2}$, the half-life of $m d m 2 \mathrm{mRNA}$ is even slightly extended to 2 to 2.5 hours. The same blots were reprobed with a $\beta$-actin cDNA, showing no changes in mRNA stability of $\beta$-actin. These results indicated that UV irradiation does not destabilize the $m d m 2$ mRNA.

To test the transcriptional regulation of the $m d m 2$ gene after UV irradiation, run-on experi- ments were performed with the nuclei isolated from the SP2/0 cells at 6 hours after treatment of $20 \mathrm{~J} / \mathrm{M}^{2} \mathrm{UV}$. Equal amounts of newly synthesized total RNA by untreated and treated nuclei were probed for transcription of $m d m 2, \mathrm{p} 21 /$ WAFl, and the control genes GAPDH and $\beta$ actin. These results are shown in Figure $6 \mathrm{E}$. At 6 hours after $20 \mathrm{~J} / \mathrm{M}^{2} \mathrm{UV}$ treatment, the transcription rates of the control genes GAPDH and $\beta$ actin were only slightly reduced as compared to the untreated nuclei. However, the transcription rate of the $m d m 2$ gene was significantly reduced while the transcription rate of the p21/WAF1 gene was substantially increased. After normalization to the GAPDH gene, the impact of UV irradiation on transcription of the other genes was compared and the results presented in Figure 6F. At 6 hours after UV irradiation, the transcription rate of the $m d m 2$ gene was reduced by $50 \%$ of the original level. On the other hand, the transcription rate of the $211 /$ WAFl gene was shown to be 2 -fold higher than in untreated cells. Since the run-on experiments only test the initiation of transcription, the differences may not quantitatively reflect all the changes observed in the steady-state levels shown by Northern analysis (Figure 6B). The steady-state level of mRNA is the balance of many determinants such as the rate of initiation of mRNA synthesis, the rate of propagation of mRNA synthesis, the rate of mRNA degradation, and the rate of transporting mRNA from the nuclei to the cytoplasm, all of which could vary at different times after UV irradiation. It is clear, however, that these results suggest that the initial decline of the $m d m 2$ mRNA after high-dose UV irradiation is controlled at least in part at the level of transcriptional initiation, possibly by a UV-responsive transcription factor or repressor of the $m d m 2$ gene that has the ability to override the positive regulation of transcriptional initiation by the $\mathrm{p} 53$ protein.

\section{DISCUSSION}

The results presented here demonstrated that the expression profile of the $m d m 2$ gene in response to UV irradiation varies as a function of UV dosage. In response to low-dose UV irradiation, the transcription of the $m d m 2$ gene is induced as early as 2.5 hours after treatment (Fig. 2). However, after high-dose UV irradiation, the expression of the $m d m 2$ gene is initially repressed to a significant extent before it is finally induced in a 


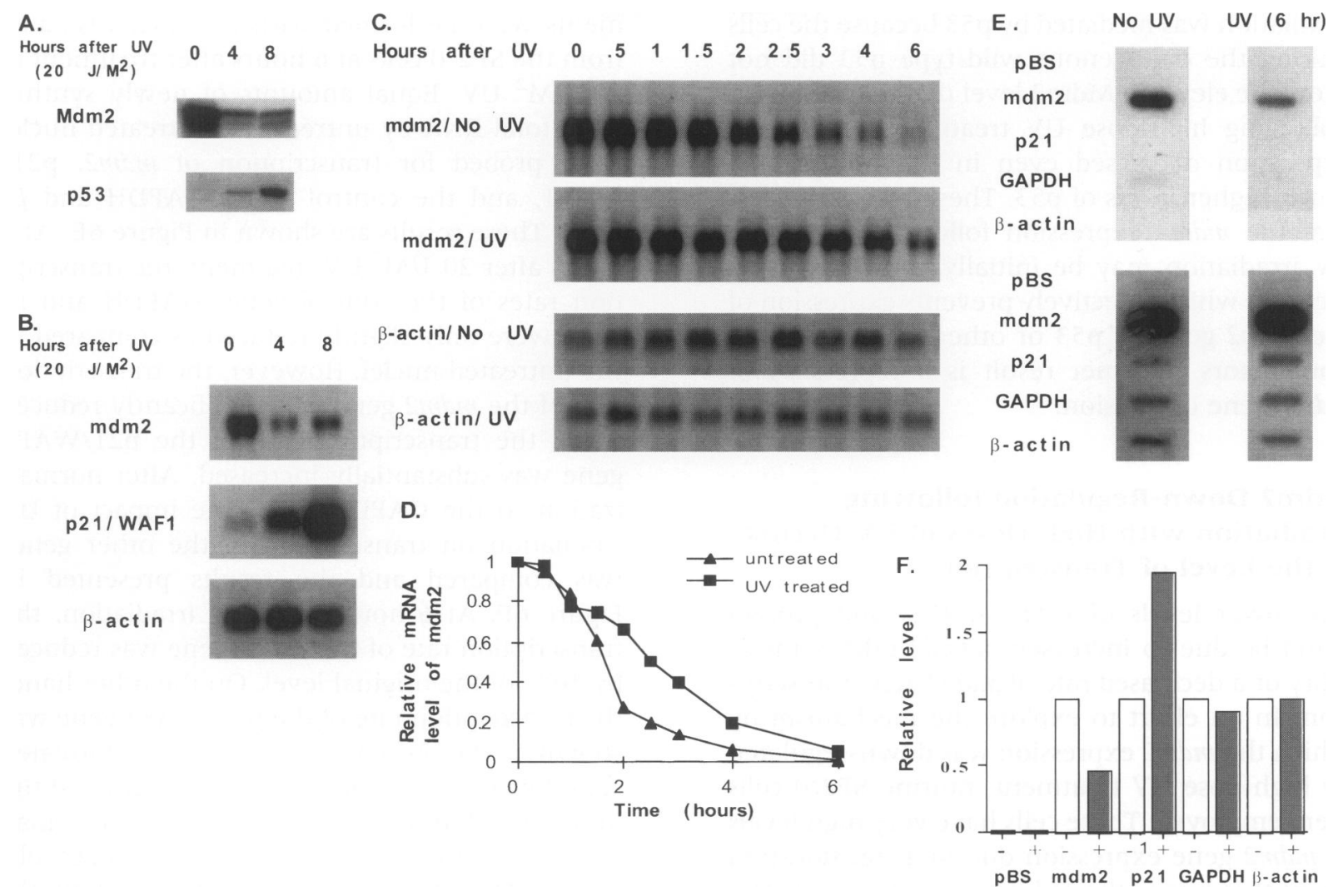

FIG. 6. The initial decrease of mdm2 expression following a high dose of UV irradiation is transcriptionally regulated

SP2/0 cells were treated with a UV dose of $20 \mathrm{~J} / \mathrm{M}^{2}$ and harvested at the indicated times. The protein levels of Mdm2 and 553 were analyzed by IP-Western (A) and the mRNA levels of mdm2, p21/WAF1, and $\beta$-actin were examined by Northern analysis (B). (C) Northern analysis of stability of the mdm2 mRNA in SP2/0 cells treated with or without UV $\left(20 \mathrm{~J} / \mathrm{M}^{2}\right)$. SP2 $/ 0$ cells were first treated with actinomycin D at a concentration of $0.5 \mu \mathrm{g} / \mathrm{ml}$ for $15 \mathrm{~min}$ and then were either irradiated with $20 \mathrm{~J} / \mathrm{M}^{2} \mathrm{UV}$ or were left untreated. Total RNA was isolated from the cells at the indicated times. $10 \mu \mathrm{g}$ of each total RNA was used for Northern blots probed with cDNAs of mdm2 and $\beta$-actin. (D) The relative amounts of mdm2 mRNA levels to the un-irradiated level were plotted as a function of time. (E) Nuclear run-on assays. The experimental procedure was described in Materials and Methods. The membranes were blotted with cDNAs of mdm2, p21/WAF1, GAPDH, $\beta$-actin, and vector pBluescript. Both light (top) and dark exposures (bottom) were taken for showing different intensities of signals on the same blots. The mdm2 signal as indicated was shown on the light exposure while the signals of p21/WAF1, GAPDH, and $\beta$-actin only appeared on the dark exposure. (F) Effects of UV on transcription of various genes.

p53-dependent fashion (Figs. 1, 3). In contrast to the induction of $m d m 2$, which is mediated by p53, the decline in the expression of the $m d m 2$ gene after high-dose UV irradiation is p53-independent (Fig. 4). These results demonstrate that this decline in $m d m 2$ expression is UV dosagedependent (Fig. 5) and appears to be controlled at the level of transcriptional initiation (Fig. 6).

The response to DNA damage in mammalian cells is very complex, involving changes in the expression of many different cellular genes. Among these, the p53 protein level is increased and it functions as a cell-cycle checkpoint by causing cell-cycle arrest or inducing apoptosis (25). Loss of p53 function contributes to tumorigenesis, likely because cells that fail to arrest in the Gl phase or pursue apoptosis after DNA damage are more likely to accumulate mutations and display genomic instability. The mechanism by which $\mathrm{p} 53$ functions is believed to be at least in part through its transcriptional activity, inducing $\mathrm{p} 21 / \mathrm{WAF}$ which contributes to cell-cycle arrest (14), or inducing Bax which facilitates apoptosis (16). Mdm2 is a negative regulator of $\mathrm{p} 53$ (11); its level is therefore important in controlling p53 checkpoint function in response to DNA 
damage. This paper demonstrates that high-dose UV irradiation induces a $m d m 2$ gene repressor in a p53 independent fashion and it blocks the synthesis of $m d m 2$ mRNA. This presumably allows time for $\mathrm{p} 53$ protein to selectively enhance transcription of genes involved in cell-cycle arrest (p21/WAF1) permitting DNA repair prior to reversal of p53-mediated effects of $m d m 2$. Conceivably, DNA damage by a low dose of UV irradiation is limited and takes less time to repair. Therefore, it is beneficial for the cell if $\mathrm{p} 53$ activity is controlled by $\mathrm{Mdm} 2$ shortly after low-dose UV irradiation. Both the early decline and delayed up-regulation of $m d m 2$ expression following a high dose of UV irradiation could well be important for modulating the transcriptional activity of p53, and thereby effectively controlling p53 function as a cell-cycle checkpoint.

Human Mdm2 has been reported to bind to the retinoblastoma ( $\mathrm{pRb}$ ) tumor suppressor protein and inhibit $\mathrm{pRb}$ growth suppression function by perturbing its regulation of E2F (28). It also has been shown that human Mdm2 directly interacts with E2F and DPl transcription factors and promotes proliferation by stimulating the activity of E2F/DPl (29). These studies suggest that $m d m 2$ may play other roles in addition to regulation of p53 activity in controlling cell-cycle progression. It will be interesting to see whether the down-regulation of the $m d m 2$ gene shortly after UV irradiation may also have important effects on the cell by reducing the stimulation of E2F/DPI activities and diminishing growth to allow DNA repair.

Understanding how expression of the $m d m 2$ gene is down-regulated in response to DNA damage will advance our knowledge of the cell-cycle regulation following DNA damaging treatment. Under normal circumstances, the expression of $m d m 2$ is controlled by two promoters, $\mathrm{P}_{1}$ and $\mathrm{P}_{2}$ (30). $P_{2}$ promotor is located near the $3^{\prime}$ end of the first intron of the $m d m 2$ gene and contains two p53-responsive elements. Transcripts from either promotor both contain the translation initiation site which is located in the exon 2 . It has been shown that transcription from the $\mathrm{P}_{2}$ promotor can be activated by either the introduction of overexpressed wild-type p53 into cells or the induction of endogenous wild-type p53 by ionizing radiation while the upstream $P_{1}$ promotor is only mildly affected by p53 (30). The results presented here demonstrate that the initial down-regulation of $m d m 2$ expression in response to a high dose of UV is controlled transcriptionally, possibly by a UV-responsive repressor or other factor(s). This putative UV-responsive factor becomes active immediately following high dosages of UV, represses the expression of the $m d m 2$ gene, and prevents the activation by $\mathrm{p} 53$ even in the presence of high levels of $p 53$ protein and the transcriptional activation of the p21/ WAFl gene. Later, presumably after DNA repair, this protein no longer represses $m d m 2$ transcription allowing the induction of $m d m 2$ by $\mathrm{p} 53$. Therefore, it is likely that a putative UV-responsive factor might well bind to a DNA sequence near or overlapping with the p53-responsive elements. Experiments which will allow the identification of such DNA sequence(s) are presently in progress. Through that DNA sequence(s), it would then be possible to identify the putative factor that binds to it. Because this factor can sense the signals from high dosages of UV which cause DNA damage, it could be an important player in the signaling pathways between DNA damage and downstream gene expression. Such a repressor is also an example of a protein that can modify p53-mediated response in selected genes. If $\mathrm{Mdm} 2$ was overproduced too early after DNA damage, it could inactivate p53-mediated functions. Thus, a mutation in this putative $m d m 2$ repressor protein could act like a suppressor of $\mathrm{p} 53$ function and possibly contribute to the cancerous phenotype. For these reasons it will be useful to identify this putative activity.

\section{ACKNOWLEDGMENTS}

The authors thank Drs. J. Hank Bayle, Stuart Lutzker, and Maureen Murphy for helpful discussions. We also thank Drs. Deborah Freedman, Maureen Murphy, and Dawn Resnick for critical reading of the manuscript. Special thanks to $\mathrm{Yu}$ qiao Shen for his help and support. This work was supported by a grant from the NCI, P0141086.

\section{REFERENCES}

1. Cahilly-Snyder L, Yang-Feng T, Francke U, George DL. (1987) Molecular analysis and chromosomal mapping of amplified genes isolated from a transformed mouse 3T3 cell line. Sem. Cell Molec. Gen. 13: 235-244.

2. Oliner JD, Kinzler KW, Meltzer PS, George D, Vogelstein B. (1992) Amplification of a gene encoding a p53-associated protein in human sarcomas. Nature 358: 80-83.

3. Leach FS, Tokino T, Meltzer P, Burrell M, 
Oliner JD, Smith S, Hill DE, Sidransky D, Kinzler KW, Vogelstein B. (1993) P53 mutations and $M D M 2$ amplification in human soft tissue sarcomas. Cancer Res. 53: 2231-2234.

4. Ladanyi $M$, Cha C, Lewis R, Jhanwar SC, Huvos AG, Healey JH. (1993) MDM2 gene amplification in metastatic osteosarcoma. Cancer Res. 53: 16-18.

5. Bueso-Ramos CE, Yang Y, deLeon E, McCown P, Stass SA, Albitar M. (1993) The human MDM-2 oncogene is overexpressed in leukemias. Blood 82: 2617-2623.

6. Sheikh MS, Shao AM, Hussain A, Fontana JA. (1993) The p53-binding protein MDM2 gene is differentially expressed in human breast carcinoma. Cancer Res. 53: 3226-3228.

7. Watanabe $T$, Hotta $T$, Ichikawa A, Kinoshita $T$, Nagai $H$, Uchida $T$, Murate $T$, Saito $H$. (1994) The MDM2 oncogene overexpression in chronic lymphocytic leukemia and lowgrade lymphoma of $\beta$-cell origin. Blood 84: 3158-3165.

8. Reifenberger G, Liu L, Ichimura K, Schmidt EE, Collins VP. (1993) Amplification and overexpression of the MDM2 gene in a subset of human malignant gliomas without p53 mutations. Cancer Res. 53: 2736-2739.

9. Fakharzadeh SS, Trusko SP, George DL. (1991) Tumorigenic potential associated with enhanced expression of a gene that is amplified in a mouse tumor cell line. $E M B O$ J. 10: 1565-1569.

10. Finlay CA. (1993) The mdm-2 oncogene can overcome wild-type p53 suppression of transformed cell growth. Mol. Cell. Biol. 13: 301-306.

11. Momand J, Zambetti GP, Olson DC, George D, Levine AJ. (1992) The mdm-2 oncogene product forms a complex with the p53 protein and inhibits p53 mediated transactivation. Cell 69: 1237-1245.

12. Barak Y, Oren M. (1992) Enhanced binding of a $95 \mathrm{Kd}$ protein to $\mathrm{p} 53$ in cells undergoing p53-mediated growth arrest. $E M B O$ J. 11: 2115-2121.

13. Chen J, Lin J, Levine AJ. (1995) The regulation of p53-mediated transcription functions by mdm-2. Mol. Med. 1: 142-152.

14. El-Deiry WS, Tokino T, Velculescu VE, Levy DB, Parsons R, Trent JM, Lin D, Mercer WE, Kinzler KW, Vogelstein B. (1993) WAF1, a potential mediator of p53 tumor suppression. Cell 75: 817-825.

15. Kastan MB, Zhan Q, El-Deiry WS, Carrier F, Jacks T, Walsh WV, Plunkett BS, Vogelstein
B, Fornace, Jr. AJ. (1992) A mammalian cell cycle checkpoint pathway utilizing p53 and GADD45 is defective in ataxia-telangiectasia. Cell 71: 587-597.

16. Miyashita T, Krajewski S, Krajewska M, Wang H-K, Lieberman D, Hoffman B, Reed J. (1994) Tumor suppressor p53 is a regulator of bcl-2 and bax gene expression in vitro and in vivo. Oncogene 9: 1799-1805.

17. Murphy M, Hinman A, Levine AJ. (1996) Wild-type p53 negatively regulates the expression of a microtubule-associated protein. Genes $\theta$ Development 10: 2971-2980.

18. Wu X, Bayle JH, Olson D, Levine AJ. (1993) The p53-mdm-2 autoregulatory feedback loop. 17: 1126-1132.

19. Juven T, Barak $Y$, Zauberman A, George DL, Oren M. (1993) Wild-type p53 can mediate sequence-specific transactivation of an internal promoter within the mdm2 gene. Oncogene 8: 3411-3416.

20. Chen JD, Wu XW, Lin JY, Levine AJ. (1996) mdm-2 inhibits the G1 arrest and apoptosis functions of the p53 tumor suppressor protein. Mol. Cell. Bio. 16: 2445-2452.

21. Montes de Oca Luna R, Wagner DS, Lozano G. (1995) Rescue of early embroynic lethality in mdm2-deficient mice by deletion of p53. Nature 378: 203-206.

22. Jones SN, Roe AE, Donehower LA, Bradley A. (1995) Rescue of embroynic lethality in $\mathrm{Mdm} 2$-deficient mice by absence of p53. $\mathrm{Na}$ ture 378: 206-208.

23. Kastan MB, Onyekwere O, Sidransky D, Vogelstein B, Craig RW. (1991) Participation of p53 protein in the cellular response to DNA damage. Cancer Res. 51: 6304-6311.

24. Lu X, Lane DP. (1993) Differential induction of transcriptionally active p 53 following UV or ionizing radiation: Defects in chromosome instability syndromes? Cell 75: 765778.

25. Perry ME, Piette J, Zawadzki J, Harvey D, Levine AJ. (1993) The mdm-2 gene is induced in response to UV light in a p53-dependent manner. Proc. Natl. Acad. Sci. USA 90: 11623-11627.

26. Chen CY, Oliner JD, Zhan Q, Fornace AJJ, Vogelstein B, Kastan MB. (1994) Interactions between $\mathrm{p} 53$ and MDM2 in a mammalian cell cycle checkpoint pathway. Proc. Natl. Acad. Sci. USA 91: 2684-2688.

27. Ausubel FM, Brent R, Kingston RE, Moore DD, Seidman JG, Smith JA, Struhl K. (1989) 
Current Protocols in Molecular Biology, Vol. 1. Greene Publishing Associates and Wiley-Interscience, New York.

28. Xiao ZX, Chen JD, Levine AL, Moditahedi N, Xing J, Sellers WR, Livingston DM. (1995) Interaction between the retinoblastoma protein and the oncoprotein MDM2. Nature 375: 694-698.

29. Martin K, Trouche D, Hagemeler C, Sø- rensen TS, La Thangue NB, Kouzarides T. (1995) Stimulation of E2F1/DP1 transcriptional activity by mdm 2 oncoprotein. Nature 375: 691-694.

30. Barak Y, Gottlieb E, Juven-Gershon T, Oren M. (1994) Regulation of $\mathrm{mdm} 2$ expression by $\mathrm{p}$ 53: Alternative promoters produce transcripts with nonidentical translation potential. Genes $\theta$ Dev. 8: 1739-1749.

Communicated by A. J. Levine. Accepted June 3, 1997. 